\title{
ベトナムのリモートセンシング事情 Remote Sensing Activities in Vietnam
}

\section{Nguyen Ngoc Thach* \\ （訳）建石隆太郎**}

ベトナムにおける宇宙およびリモートセンシングの 活動の総元締めは National Centre for Natural Science and Technology (NCST)である。NCST の仕事 は, 国の経済発展のため宇宙技術やリモートセンシン グ技術の結果を如何に利用するかの計画を行うことで ある。

実際の研究や開発は約20の研究所で行われている。 例之ば, Institute of Physics, Institute of Geography, Institute of Geology, Institute of Agricultural Planning and Projection, Forest Inventory and Planning Institute, General Department of Geodesy and Cartography, Institute of Geology and Mineral Resources, Institute of Water Resources Planning and Management などである。NCST が行うことは, リモートセンシングに関係する研究所間の連絡調整,

リモートセンシングデータの入手, リモートセンシン グのユーザー機関に対する技術援助である。

開発途上国として，ベトナムは経済発展のため天然 資源や環境状況を調査するリモートセンシング技術を 国の発展のための基本的な要素の一つと考之ている。 このため,リモートセンシングは重視されている。特 に, 土地利用, 土壤, 水資源, 森林, 洪水, 植生, 沿 岸変化, 浸食などの情報をりモートセンシングにより 収集し, 農業開発の計画に役立てることが重要である。 ベトナムの国土は約 $330,000 \mathrm{~km}^{2}$ で複雑な地形, 地質 を持っており，モンスーン地域に位置する。人口は約 7,000万人で農業経済国である。したがって，環境保全 を考慮した開発計画のため, 森林, 農業, 水産の分野 における天然資源の正確な調查が急がれている。また, リモートセンシング技術の効率的な情報収集能力は地

* Institute of Geography, National Centre for Natural Science and Technology, Vietnam

**千葉大学環境リモートセンシング研究センター

「写真測量とリモートセンシング」Vol. 35, No. 1, 1996
質調査や気象予報の分野でも重要である。

ベトナムでリモートセンシングに従事している研究 者の数は約 200 人である。デー夕処理, 教育・トレーニ ング，データ保存・配布などを行う施設がある。

政府機関はリモートセンシング技術を多くの計画に 利用するための子算を持っている。また, ESCAP/ UNDPからも資金援助を受けてリモートセンシング プロジェクトを行っている。

GMS の雲画像が天気予報・サイクロン警報に使われている。 現在, サイクロンの形態, 構造, 動きなどの研究が行 われている。

気象衛星からの写真が気象予報に利用されるのと同 様に Landsat 画像は地質図作成に重要である。Landsat データから中央高原地域, メコン川デル夕地域の 縮尺 25 万分の 1 の土地利用図が作られた。また，この 地域の土壌図を改訂する際にも Landsat データが用 いられた。いくつかの地方では航空写真から縮尺 5 万 分の 1 あるいは 1 万分の 1 の土地利用図が作られてい る。衛星画像を用いて, 縮尺 600 万分の 1 の地質構造図 も作成されている。

Red river（ハノイを流れる）やメコン川を観測した Landsat およびSPOT の画像は浸食や生物評価など 沿岸地域の研究に用いられている。

Landsat MSS画像はインドの National Remote Sensing Agency (NRSA), タイの National Research Council of Thailand (NRCT), 米国のいくつかの研 究所から入手している。SPOT 画像はフランスから直 接, あるいは夕イの SPOT 配布機関から入手してい る。

森林の分野ではりモートセンシングは森林伐採を管 理するための植生困編集に利用されている。森林の変 化をモニタリングするためにディジタル画像処理技術 が用いられている。ある地域では材木量を推定するた 
めに高解像度データが用いられている。

海洋の分野ではクロロフィル濃度の推定やサンゴ礁 の地図化にリモートセンシングが利用されている。ま た, 土堙・資源管理, 環境管理, 地下水調査, 水資源 生態研究, 災害現象研究にもりモートセンシングが利 用されている。

農業の分野では, SPOT 画像を用いてモンスーン洪 水地域の調查を行っている。また，土堙夕イプ境界を 更新するため航空写真も用いている。

ハッセルブラッド航岱機用マルチスペクトルカメラ は種々の実用目的に高解像度・大縮尺の画像を得るの に用いられている。

UNDP と FAO の援助で "Utilisation of Remote Sensing data for assessment of agricultural resources”といjプロジェクトが行われた。このプロ ジェクトでInstitute of Physicsに写真判読装置と ディジタルおよびアナログ画像処理装置が設置され た。この装置を用いて, 地質図, 中央高原地域, メコ ン川デル夕地域の土壌図, 土地利用図などが作られた。 地域りモートセンシングプログラムの援助で，Red river, メコン川の低地における自然状態, 天然資源の 評価のためにリモートセンシングデータを解析するプ ロジェクトが成功裏に完了した。このプロジェクトの 目的は Landsat, SPOT データを用いて浸食, 生物変 化を含む沿岸地域の調查を行うことである。

ここ 2,3 年, 地理情報システム (GIS) の利用が進 んできた。GISは Ministry of Forestry, Ministry of Agriculture, General Department of Cartography and Geodesy などの機関で利用されてきている。これ らの機関の間のつながりは衛星画像を融通し合うこと に限られている。GISは主に環境影響評価，土地利用 解析, 主題図作成のために利用されている。成果品と しては, 全国土の 100 万分の 1 の数值化基本図, ある地 域での 5 万分の 1 の数值化地形図, 10 万分の 1 の数值 化水深図，ある地域での 5 万分の 1 の主題図からの データベースなどである。

ARC/INFO, ILWIS, SPAINなどのいくつかの GIS ソフトウェアがVGA モニター, ディジタイザ, ラ インプリンタなどの周辺装置のもとで使われている。 GIS に関する研究活動は地方における実用目的のため のソフトウェア開発に主眼が置かれている。C 言語に よる IBM/PC コンパティブルの環境のもとでいくつ かの「環境資源情報システム」(Environmental and
Resource Information System) が開発された。この システムは実用のため地方の機関に配布されている。

現在, リモートセンシングの 5 ケ年計画を設定しつ つある。その主要なものは以下のとおりである。

一 リモートセンシングに関する設備・施設の整備

- Red riverの流域管理, 沿岸地域の管理と漁業 指導, 土地被覆の地図化および環境保全

- 土壌劣化の地図化, 地質図作成, 植生図作成

NCSTのリモートセンシング専門家は, 大学での講 義, トレーニングコース, セミナーを通して教育活動 をも行っている。国際協力のおかげで，毎年多くの専 門家がトレーニングのため海外の先進的な研究機関を 訪問したり，国際会議に参加したりしている。

リモートセンシング技術がまだベトナムで用いられ ていなかった頃, 如何なるデー夕収集も困難であった。 リモートセンシング技術はタイムリーに十分な情報を 提係してくれる。反復観測はその間の変化の検出・評 価を可能にする。リモートセンシングで得られる情報 は天然資源の地図化・管理に用いられる。Landsat 画 像により,より安い経費で短時間に土地利用図, 土地 被覆困が更新されるようになった。

リモートセンシング技術の利用による経済的効果 は, より広い地域に適用するほど, 大きくなる。リモー トセンシング技術導入による出費を軽减するための重 要な要素の 1 つは管理の効果的な方法である。すなわ ち，異なる機関での重複を避けるべきである。

リモートセンシングはベトナムにとって新しく導入 された技術である。この可能性のある技術により我及 は今までに少しばかりの成果を得た。この技術をべト ナムで発展させるために我々は国際協力, 特に近隣諸 国との協力を望んでいる。

参考のためにリモートセンシングに関係する機関の 図を示す。

\section{(訳者後記)}

著者の Nguyen Ngoc Thach は，訳者が1995年11月 にベトナムを訪問した際に会った地質の専門家であ る。この報告では大学についてはあまり触れていない ので少し追加する。

- Hanoi National University の地理学部は以下の 8 つの部門から式っている。Geography, Geology, Morphology, Remote Sensing and Cartography, Meteorology, Hydrology, Maritime, Ecosystem and 
Environment.この中で, リモートセンシングは Remote Sensing and Cartographyに含まれており， 先生が 5 人いる。コンピュー夕設備は不十分でパソコ ンが $2 ， 3$ 台あるだけである。この大学ではリモート センシングの修士課程を作りたがっているが予算が十 分にない。ベトナムの北西端, ラオスと中国の国境の 近くの Lai Chau という地方の環境モニタリングプロ 湆クトが 5 ケ年計画でスタートしており, 海外から の援助協力を希望している。日本との人材交流，研究 協力を希望している。

- Technical University of Mining and Geology (Hanoi) および Polytechnic College of Ho Chi Minh Cityでもリモートセンシングを行っている。Hanoi National University が応用指向あるいは理学的であ るのに対し, Technical University of Mining and Geology は工学的，データ処理主導型である。

一 ベトナムにはリモートセンシングの学会, 協会は まだない。したがって, 大学, 国立研究所を通じた横 のつながりはあまりない。

一 本報告の著者は Institute of Geography の地質関 係の部門に属しているが，ここには Remote Sensing Technology and GIS Department (RESTGIS) とい うリモートセンシングと GIS 専門の部門があり，7人 のスタッフと大学のリモートセンシング関係研究室以 上のコンピュータ設備がある。

一 ベトナムは現在, 直接経済発展に結びつくものが 重視されており,科学研究に対する予算は十分でない。 1996年 6 月には 4 年に一度の国政選挙があり, 研究者 はこの選挙を機に国の方針が変わり子算が増えるのを 期待している。

一 本報告の著者に直接確認したところ, ベトナムに おけるリモートセンシングの実質的なリーダー シップはNCSTがもっている。しかし, 各省庁で もリモートセンシング関係機関があるので，これ らの調整をするため最近 NCSRA（四参照）が設 立された。

一 最後に訳者が撮った写真を示す。

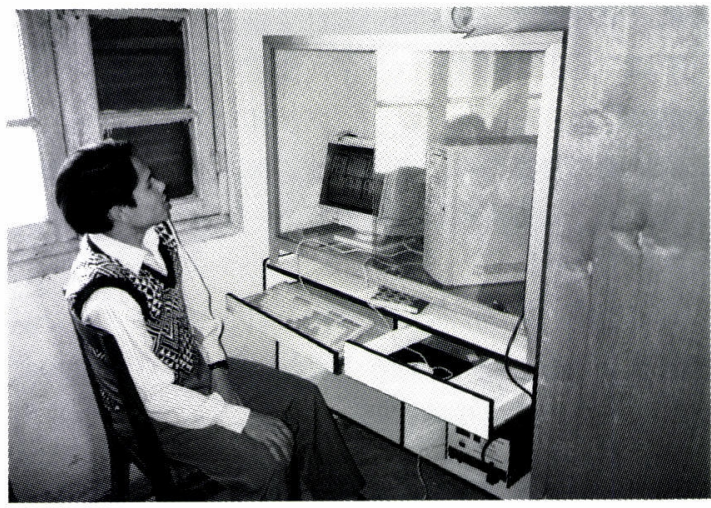

写真 1 Hanoi National University の研究室内の防塵, 防 湿のためケースに入ったパソコン

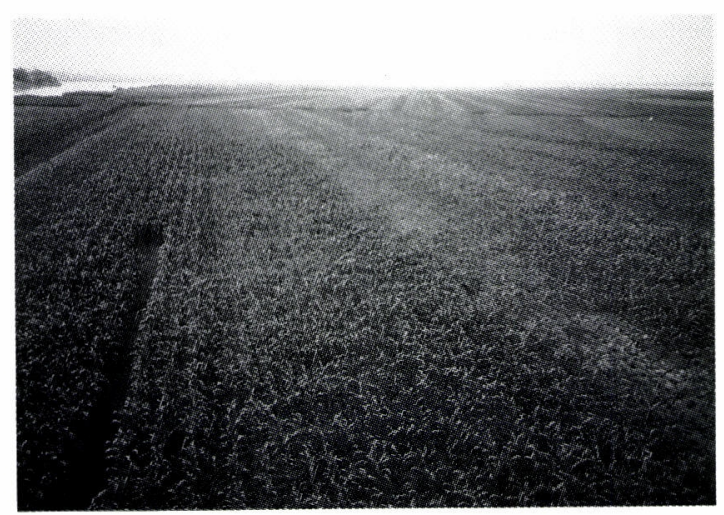

写真 2 ハノイを流れる Red river の中州のとうもろこし 畑

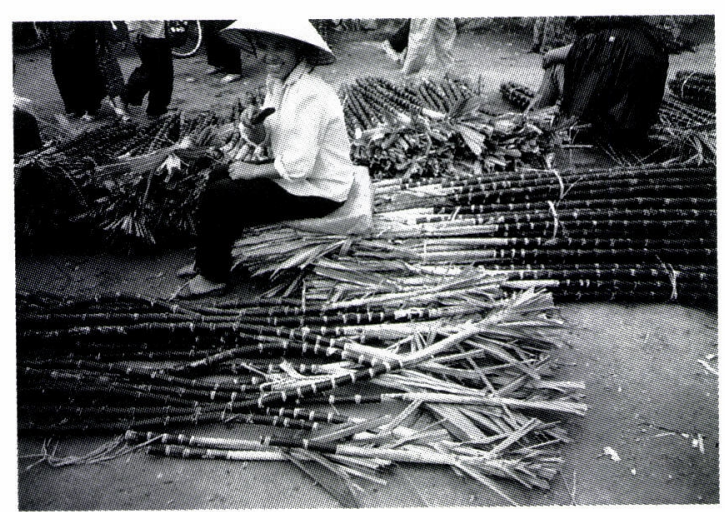

写真 3 Kim Boi 村の市場のさとうきび 


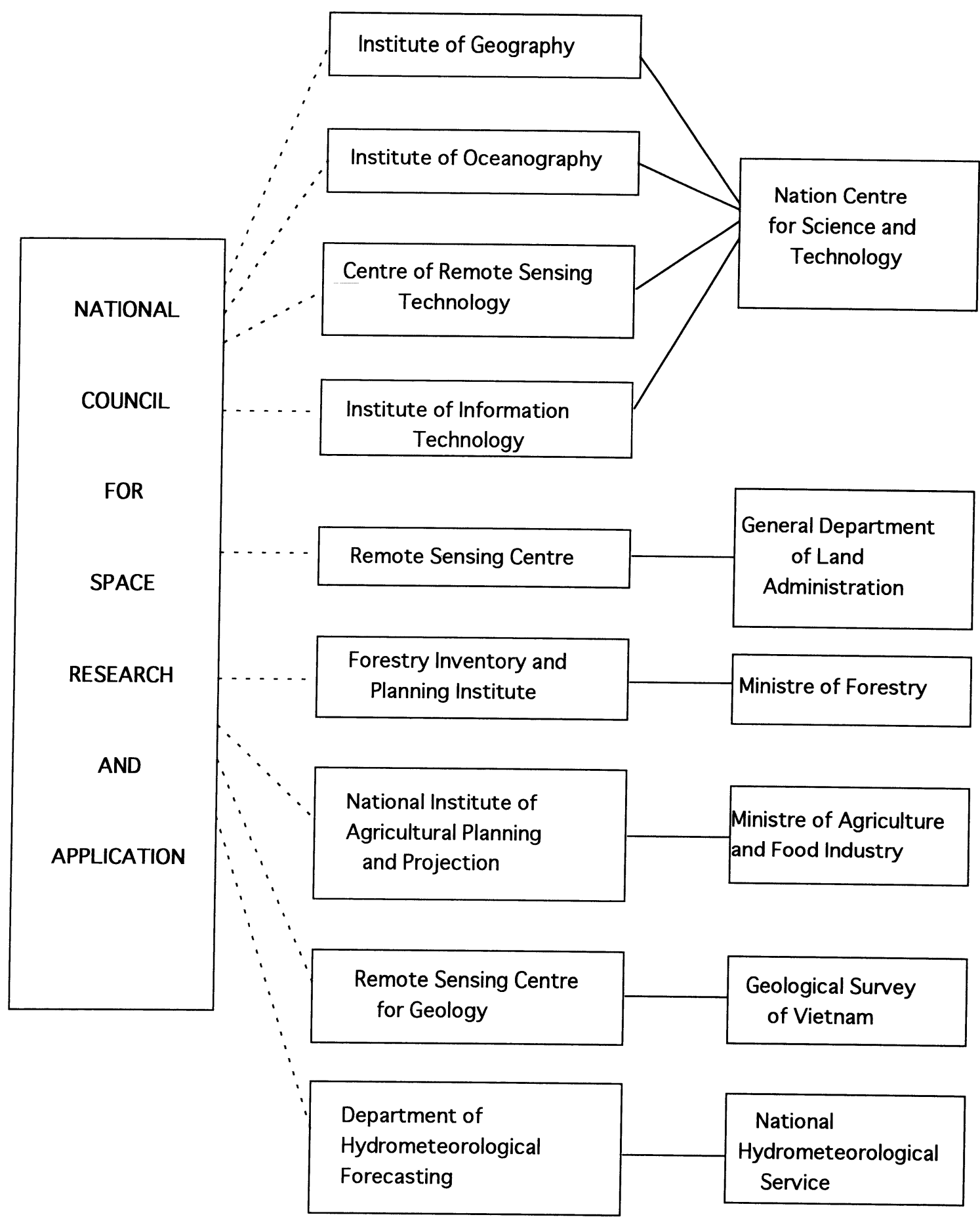

Note :

Solid lines : Ministeral direct leadership

Dashed lines : National coordination 